\title{
A Secretory Cellulose-Binding Protein cDNA Cloned from the Root-Knot Nematode (Meloidogyne incognita)
}

\author{
X. Ding, J. Shields, R. Allen, and R. S. Hussey \\ Department of Plant Pathology, University of Georgia, Athens 30602-7274, U.S.A. \\ Accepted 30 June 1998.
}

\begin{abstract}
A cDNA encoding a secretory cellulose-binding protein was cloned from the root-knot nematode (Meloidogyne incognita) with RNA fingerprinting. The putative full-length cDNA, named $M i$-cbp-1, encoded a 203 amino acid protein containing an $\mathrm{N}$-terminal secretion signal peptide. The $\mathrm{C}$ terminal sequence of the putative MI-CBP-1 was similar to a bacterial-type cellulose-binding domain, whereas the $\mathrm{N}$-terminal sequence did not show significant similarity to any proteins in data bases. Recombinant MI-CBP-1 lacked cellulase activity, but bound to cellulose and plant cell walls. In Southern blot hybridization, Mi-cbp-1 hybridized with genomic DNA from $M$. incognita, $M$. arenaria, and $M$. javanica, but not $M$. hapla, Heterodera glycines, or Caenorhabditis elegans. Polyclonal antibodies raised against recombinant MI-CBP-1 strongly labeled secretory granules in subventral gland cells of second-stage juveniles in indirect immunofluorescence microscopy. Enzymelinked immunosorbent assay detection of MI-CBP-1 in stylet secretions of second-stage juveniles with the polyclonal antibodies indicated MI-CBP-1 could be secreted through the nematodes' stylet, suggesting that the cellulose-binding protein may have a role in pathogenesis.
\end{abstract}

Additional keywords: feeding, giant-cell.

The sedentary, endoparasitic, root-knot nematode (Meloidogyne spp.) is a major contributor to annual yield losses (US $\$ 77$ billion) caused by plant-parasitic nematodes to world crops (Sasser and Freckman 1987). This obligate, biotrophic parasite has evolved a very specialized and complex feeding relationship with susceptible host plants. Pathogenesis by root-knot nematodes has been extensively studied (Wyss et al. 1992; Jones and Payne 1978) and reviewed (Hussey et al. 1994; Hussey 1985; Williamson and Hussey 1996). However, knowledge about the mechanism of pathogenesis is still fragmentary, especially at the molecular level. The infective second-stage juvenile (J2) penetrates roots near the zone of elongation by destroying the epidermal cells through either mechanical force with its protrusible stylet, enzymatic digestion of cell walls by esophageal gland cell secretions emitted through the stylet, or both. The $\mathrm{J} 2$ then moves toward the root tip intercellularly along the middle lamellae in the cortical tis-

Corresponding author: R. S. Hussey; Fax: 1-706-542-1262; E-mail: hussey@caes.arches.uga.edu

Nucleotide and/or amino acid sequence data have been submitted to the GenBank data base as accession number AF049139. sue to the meristematic zone, where it turns around to enter the center of the root and migrates to the differentiating vascular cylinder (Wyss et al. 1992). When differentiating vascular tissue is reached, the $\mathrm{J} 2$ transforms five to seven root cells into permanent specialized feeding cells, called giantcells, by modifying and regulating cell phenotype, function, and metabolism. The nematode is entirely dependent on the giant-cells for nourishment for development and reproduction.

Giant-cells are enlarged, multinucleate cells with elaborate wall ingrowths and an expanded and dense cytoplasm that is metabolically active. The specialized giant-cells are similar to transfer cells in phenotype (Jones and Payne 1978), but their induction and maintenance depend entirely on the feeding activities of the root-knot nematode (Hussey et al. 1994). Although the induction mechanism is still unknown, several lines of evidence suggest that bioactive molecules synthesized in the nematode's esophageal gland cells and secreted through its stylet may be either directly or indirectly involved in giantcell induction and maintenance in addition to having other roles in the infection process (Williamson and Hussey 1996). In fact, cellulases, which have a putative role in the infection process, have recently been shown to be synthesized in the subventral gland cells of cyst nematodes and the corresponding cDNAs have been cloned (Smant et al. 1998). Root-knot nematode infective $\mathrm{J} 2$ and adult females contain one dorsal and two subventral gland cells where secretory proteins are synthesized and packaged in Golgi-derived, membrane-bound, secretory granules (Hussey et al. 1994; Hussey and Mims 1990). Monoclonal antibody studies showed that proteins from both subventral and dorsal gland cells are components of stylet secretions (Davis et al. 1994). Therefore, characterization of stylet secretions is critical for elucidating the mechanism of pathogenesis.

In this study, RNA fingerprinting was used to identify RNAs present in the parasitic $\mathbf{J} 2$ of $M$. incognita but absent or reduced in pre-parasitic $\mathrm{J} 2$. A cDNA encoding a secretory cellulose-binding protein was cloned from $M$. incognita.

\section{RESULTS}

RNA fingerprinting and cloning of the cDNA.

A total of 65 different primer combinations were used in the RNA fingerprinting reactions. Fifty-four cDNA fragments that were specific or more strongly expressed for parasitic $\mathrm{J} 2$ were cloned and sequenced after selecting against pre-parasitic J2. The predicted protein sequence of one fragment, F43, was similar to a bacterial-type cellulose-binding domain (CBD) 
based on a BLAST search (Altschul et al. 1990) against the GenBank/EMBL data base. In Northern (RNA) blot analysis, an approximately $1-\mathrm{kb}$ transcript was detected in pre-parasitic and parasitic $\mathrm{J} 2$ but not in adult females when the F43 fragment was used as a probe (data not shown). Therefore, the same probe was used to screen an $M$. incognita J2 cDNA library. Six positive clones were identified and digestion of plasmids isolated from these clones with $\mathrm{XhoI} /$ Bst XII released 0.8 - to $1.0-\mathrm{kb}$ inserts. The clone with the longest cDNA insert, named $M i-c b p-1$, was selected for further characterization.

\section{Predicted amino acid sequence of the $M i-c b p-1$ clone.}

Mi-cbp- 1 contained 998 nucleotides with a putative open reading frame (ORF) of $609 \mathrm{bp}$ (Fig. 1). Sequence analysis of $M i-c b p-1$ based on the GCG program (Genetics Computer Group, Madison, WI) revealed that the ORF encoded a putative protein of 203 amino acids, with an eukaryotic secretion signal sequence (Nielsen et al. 1997) terminating at amino acid residue 20 (Fig. 1).

Computer-assisted protein sequence similarity search (Altschul et al. 1990; Smith and Smith 1992) revealed that the C-terminal 95 amino acids of MI-CBP-1 had 21 to $24 \%$ identity with type II CBD from different bacterial origins and 24 to $25 \%$ identity with CBDs in two $\beta$-1,4-endoglucanases from cyst nematodes (Fig. 2) (Smant et al. 1998). The sequence contained all the characteristic CBD structural features (Gilkes et al. 1991), such as high numbers of hydroxy amino acids, a deficiency in charged amino acids, and conserved tryptophan, asparagine, and glycine residues. The $\mathrm{N}$-terminal 71 amino acid sequence of MI-CBP-1 did not show similarity to any proteins in the data base. The $\mathrm{N}$ - and $\mathrm{C}$-terminal sequences were connected by a serine-rich 16 amino acid Qtype linker (Gilkes et al. 1991), where an N-glycosylation site (NGSS) was detected (Bairoch et al. 1995) (Fig. 1).

\section{Southern blot hybridization.}

To determine if genes analogous to $M i-c b p-1$ were present in other nematode species, Mi-cbp-1 was radiolabeled and used to probe Southern blots containing EcoRI-digested total DNA from five plant-parasitic nematodes, the free-living nematode Caenorhabditis elegans, and soybean. The Mi-cbp1 probe detected analogous sequences in three Meloidogyne spp.: $M$. incognita, $M$. arenaria, and $M$. javanica. No hybridization at high stringency was observed with genomic DNA from M. hapla, Heterodera glycines, C. elegans, or the host plant, soybean (Fig. 3). Identical hybridization patterns also were observed under low stringency conditions.

\section{Immunological analyses.}

A polyclonal antiserum was raised against recombinant MICBP-1 for immunological analyses. To determine the location of the MI-CBP-1 in the nematode, sections of pre-parasitic J2 of $M$. incognita, $M$. arenaria, $M$. javanica, M. hapla, and $H$. glycines and mixed stages of $C$. elegans were treated with the polyclonal antiserum in immunofluorescence assays. For the pre-parasitic $\mathrm{J} 2$ of $M$. incognita, M. arenaria, M. javanica, and $M$. hapla, the antibodies reacted strongly and specifically with secretory granules in the subventral gland cells and their cytoplasmic extension and expanded ampullae, which are located posterior to the pump chamber in the metacarpus (Fig. 4A). The labeling pattern for the $M$. incognita parasitic J2 was identical to that observed for the pre-parasitic J2. No labeling was observed with the adult females of $M$. incognita or the pre-parasitic $\mathrm{J} 2$ of $H$. glycines and mixed stages of $C$. elegans. To establish that MI-CBP-1 can be secreted through the stylet of pre-parasitic $M$. incognita $\mathrm{J} 2$, stylet secretions were induced in vitro and concentrated for use in an enzyme-linked immunosorbent assay (ELISA) with the MI-CBP-1 polyclonal antibody. MI-CBP-1 was detected in the stylet secretions and total extracts of $\mathrm{J} 2$ by the polyclonal antibodies (Fig. 5).

The putative cellulose-binding function of the CBD of MICBP-1 was confirmed by cellulose-binding assays and recombinant MI-CBP-1 binding to tobacco cell walls. The $29-\mathrm{kDa}$ recombinant MI-CBP-1 was eluted from a cellulose resin column as determined by sodium dodecyl sulfate-polyacrylamide gel electrophoresis (SDS-PAGE) and Coomassie blue staining, indicating the ability of the CBD to bind to cellulose (Fig. 6). Another M. incognita recombinant protein, MI-AMP-1,

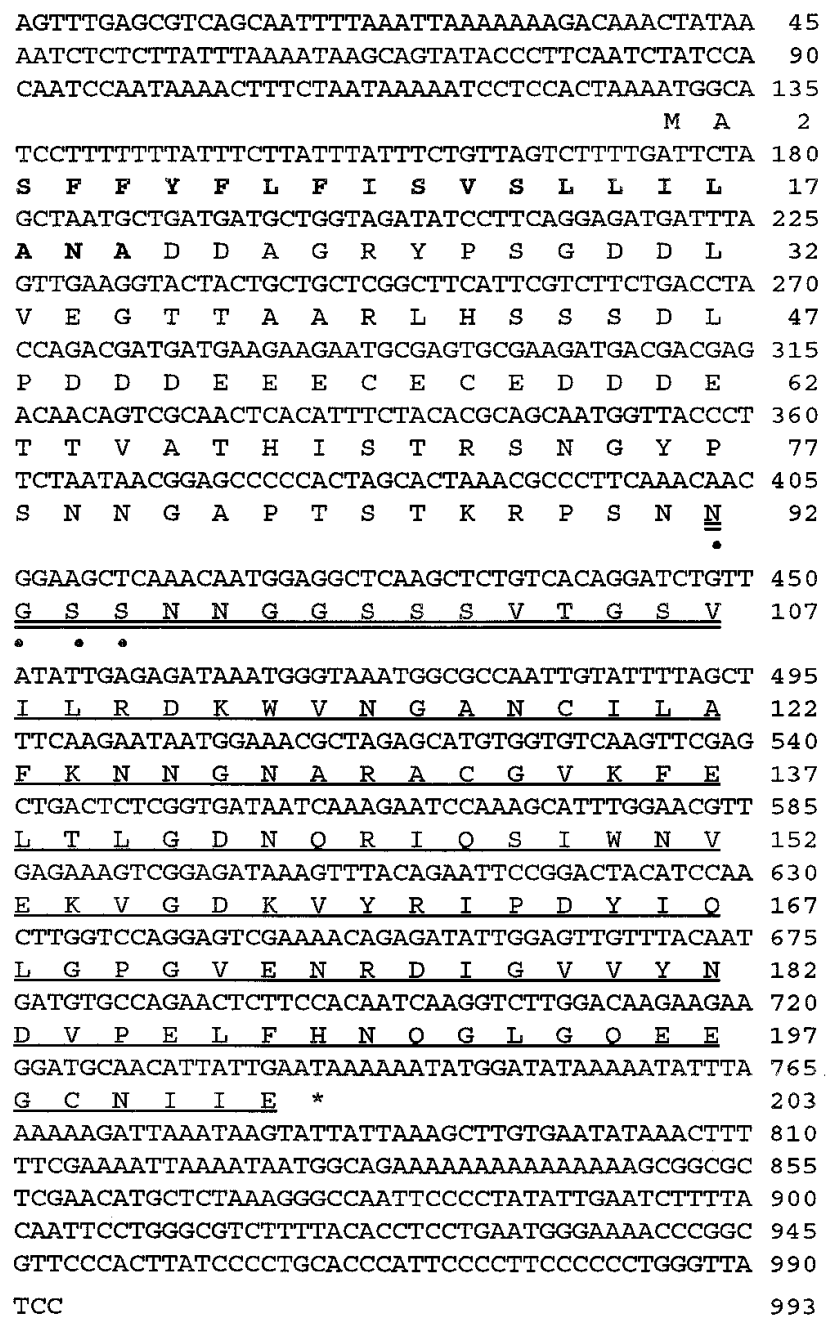

Fig. 1. cDNA and predicted amino acid sequence of $M i-c b p-1$ from Meloidogyne incognita. Putative secretion signal peptide indicated in bold. Linker separating N-terminal sequence from cellulose-binding domain is double underlined. Putative N-glycosylation site indicated by solid circles. Cellulose-binding domain sequence marked by a single underline. TAA translation termination signal marked with an asterisk. Nucleotide sequence has been submitted to GenBank data base as accession number AF049139. 
without a CBD was used as a control. MI-AMP-1 did not bind to the cellulose resin and subsequently was not detected in the polyacrylamide gel. Tobacco BY-2 cells were used to assess the ability of the recombinant MI-CBP-1 to bind to plant cell walls in an indirect immunofluorescence assay with the MICBP-1 polyclonal antiserum. These assays showed that the recombinant MI-CBP-1 strongly bound to walls of tobacco cells (Fig. 4B). A polyclonal antibody to MI-AMP-1 and the secondary antibody alone did not bind to the cell walls (data not shown).

To exclude the possibility that the MI-CBP-1 polyclonal antiserum recognized other $\mathrm{CBD}$-containing proteins in the immunoassays, the 228-bp fragment containing the CBD sequence of $M i-c b p-1$ was subcloned and overexpressed to obtain recombinant $\mathrm{CBD}$. The $17-\mathrm{kDa}$ recombinant $\mathrm{CBD}$ and the recombinant MI-CBP-1 were detected in immunoblots with the MI-CBP-1 polyclonal antiserum (Fig. 7). In immunoblots, the MI-CBP-1 polyclonal antiserum recognized a diffuse band (approximately $43 \mathrm{kDa}$ ) in extracts of $M$. incognita $\mathrm{J} 2$ that had a higher $M_{\mathrm{r}}$ than the recombinant MI-CBP-1, possibly because of glycosylation (Fig. 7). CBD-specific antibodies in the MICBP-1 polyclonal antiserum were removed by absorption to recombinant $\mathrm{CBD}$. In all immunoassays when the CBDabsorbed MI-CBP-1 polyclonal antiserum was substituted for the original MI-CBP-1 polyclonal antiserum, the results were identical to those derived from use of the nonabsorbed MICBP-1 polyclonal antibodies (data not shown).

\section{$\beta-1,4$-glucanase assay.}

A $\beta$-1,4-glucanase assay with agarose plates was conducted to test for cellulase activity by the recombinant MI-CBP-1. In this assay, the recombinant MI-CBP-1 did not show any $\beta$ 1,4-glucanase activity, whereas the positive control, cellulase from Aspergillus niger, produced a well-defined zone of activity (Fig. 8).

\section{DISCUSSION}

Esophageal gland cell secretory proteins delivered through the root-knot nematode's stylet are thought to have a critical role in pathogenesis (Williamson and Hussey 1996). The $\mathrm{Mi}$ $c b p-1$ cDNA cloned from $M$. incognita parasitic $\mathrm{J} 2$ encoded a subventral gland cell secretory protein that was present in pre-parasitic and parasitic $\mathrm{J} 2$ and was a component of stylet secretions. Synthesis of MI-CBP-1 in the esophageal gland cells was confirmed by immunolocalization of the MI-CBP1 in subventral gland cells of $\mathrm{J} 2$. The presence of an $\mathrm{N}$ terminal signal peptide indicated that MI-CBP-1 was a secretory protein.

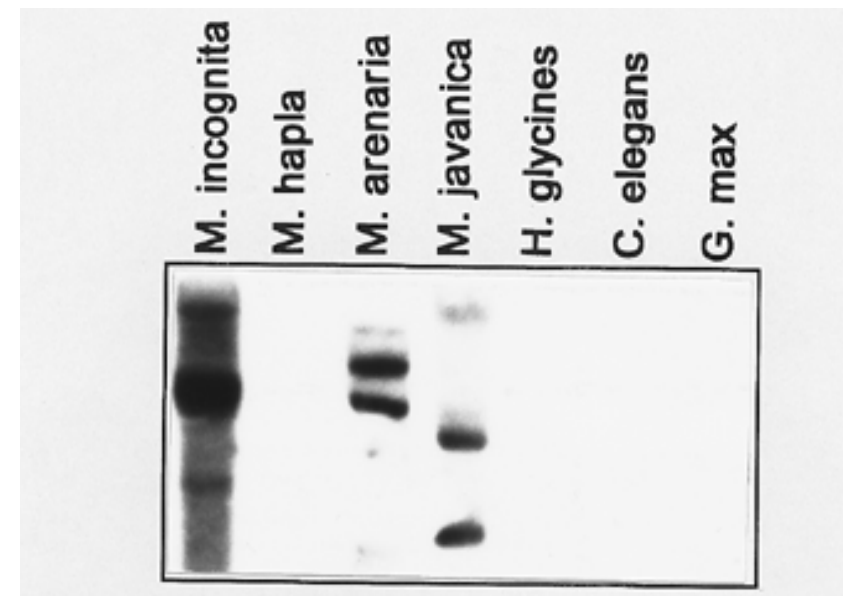

Fig. 3. Southern blot hybridization of genomic DNA from five nematode species (Meloidogyne incognita, M. hapla, M. arenaria, M. javanica, Heterodera glycines, Caenorhabditis elegans) and soybean (Glycines max). DNA $(10 \mu \mathrm{g})$ was digested with EcoRI, fractionated in $1 \%$ agarose, transferred onto a nylon membrane, and probed with the ${ }^{32} \mathrm{P}$ labeled Mi-cbp-1.

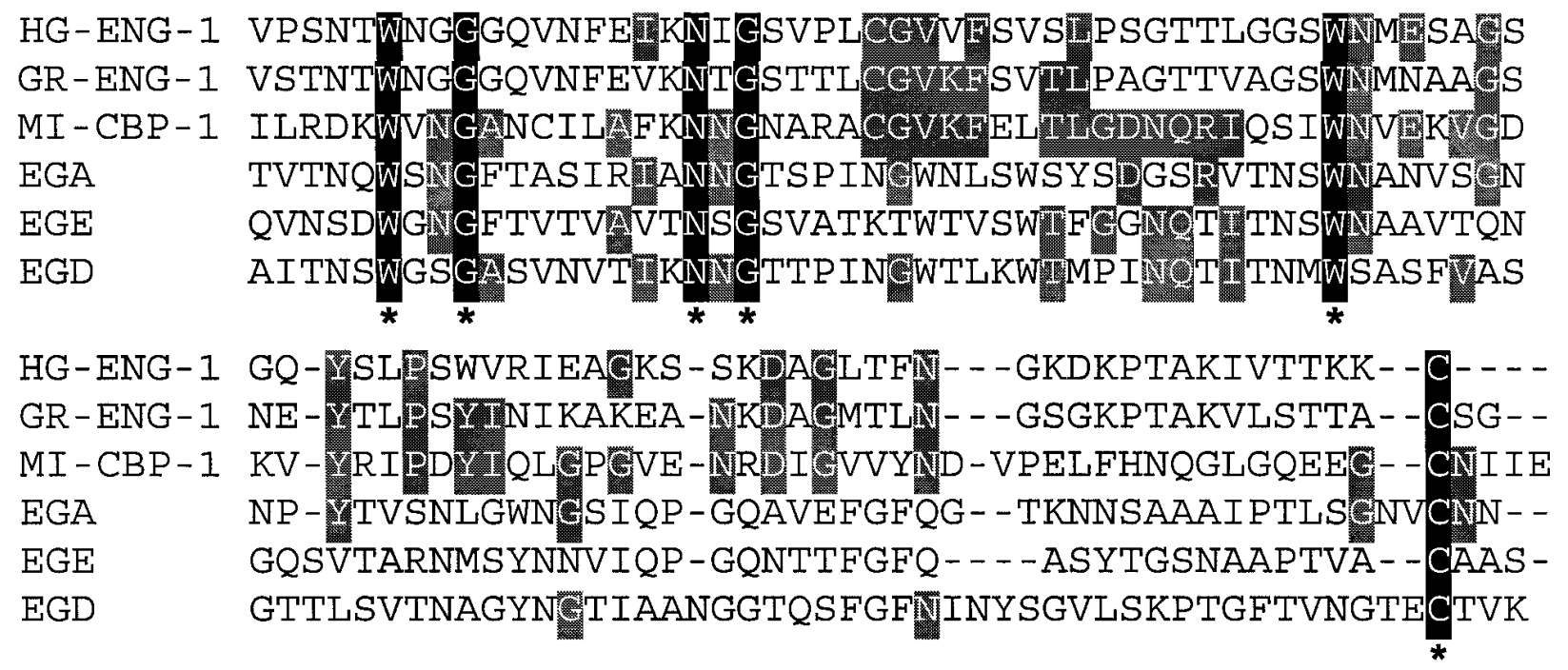

Fig. 2. Sequence alignment between deduced amino acid sequence of cellulose-binding domain of MI-CBP-1 from Meloidogyne incognita with cellulose-binding domains from other organisms. HG-ENG-1, $\beta$-1,4-endoglucanase from Heterodera glycines (GenBank accession no. AF006052); GR-ENG1, $\beta$-1,4-endoglucanase from Globodera rostochiensis (AF004523); MI-CBP-1, cellulose-binding protein from M. incognita (AF049139); EGA, endoglucanase A precursor from Pseudomonas fluorescencens (P10476); EGE, cellulase E1 from Acidothermus cellulolyticus (P54583); EGD, endoglucanase D precursor from Clostridium cellulovorans (P28623). Residues identical to those of MI-CBP-1 are shaded, residues conserved in all molecules are marked with black shadow and asterisks. 
Mi-cbp- 1 was Meloidogyne-specific and not detected in $H$. glycines, which has a different mechanism of pathogenesis, or C. elegans, which feeds on bacteria. Interestingly, Mi-cbp-1 did not hybridize under high and low stringency with genomic DNA from M. hapla in the Southern blot but the polyclonal antisera detected MI-CBP-1 in the subventral gland cells of pre-parasitic J2 of this species. The detection of MI-CBP-1 in the subventral gland cells of pre-parasitic and parasitic $\mathrm{J} 2$ and not in adult females in the immunofluorescence assays suggests that MI-CBP-1 may only be involved in the early stages of root infection by the $M$. incognita J2. During development of the parasitic $M$. incognita $\mathrm{J} 2$, the size of the subventral gland cells and the number of the secretory granules they contain gradually decrease, while the dorsal gland cell enlarges and forms large quantities of secretory granules to become the principal esophageal gland cell in the female (Hussey and Mims 1990).

A putative role of MI-CBP-1 in pathogenesis was suggested by the detection of the cellulose-binding protein in $\mathrm{J} 2$ stylet secretions. The synthesis of $\beta-1,4$-endoglucanases in subventral gland cells of cyst nematodes and their secretion through the nematode's stylet have established the importance of subventral gland cell secretions in pathogenesis (Smant et al.
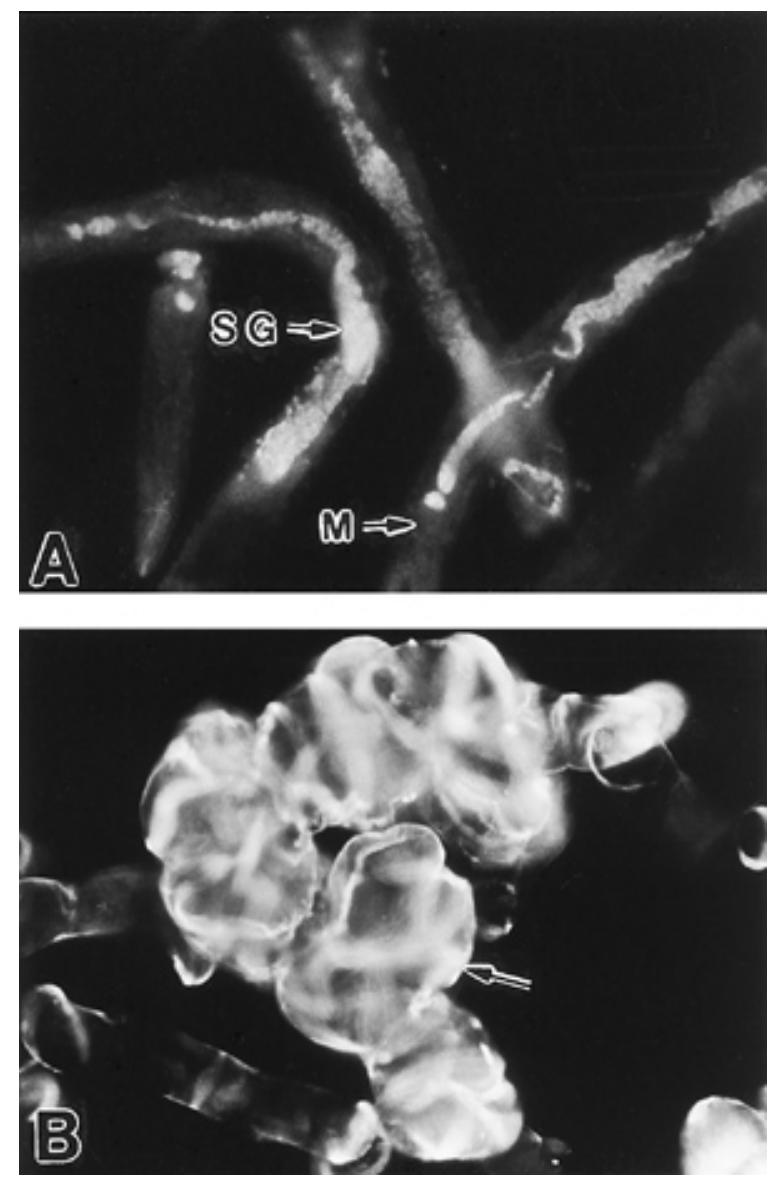

Fig. 4. Indirect immunofluorescence microscopy with polyclonal antiserum to MI-CBP-1. A, Labeling of subventral esophageal gland cells (SG) of pre-parasitic, second-stage juveniles of Meloidogyne incognita with MI-CBP-1 polyclonal antiserum. $\mathrm{M}=$ metacorpus. B, Labeling of recombinant MI-CBP-1 bound to walls of tobacco cells. Intense labeling occurs at crosswalls (arrow).
1998) The high similarity of the C-terminal sequence of MICBP-1 to CBDs suggested that the protein might bind to cellulose, which was confirmed in cellulose-binding assays as well as binding to tobacco cell walls. The binding to cellulose suggests that the MI-CBP-1 might be involved indirectly in cellulose degradation or might be used as an anchor to support other (as yet unknown) function(s).

Cellulose is one of the major components of plant cell walls. Many plant pathogens use a complex of cellulases and other hydrolytic enzymes during pathogenesis. That endoparasitic nematodes might use a similar strategy during penetration and migration in roots is supported by the cloning of $\beta$ 1,4-endoglucanase cDNAs from cyst nematodes (Smant et al. 1998) and from root-knot nematodes (Marie-Noell Rosso, personal communication). MI-CBP-1 might be a member of the complex cellulase system (Gilkes et al. 1991) and assist other CBD-lacking cellulases to bind to cellulose since neither cellulase activity nor a catalytic domain were detected in the sequence for MI-CBP-1. Nevertheless, the CBD of MI-CBP-1 only has $43.5 \%$ identity with CBDs of cellulases from rootknot nematodes (Marie-Noell Rosso, personal communication) even though they have the same common structural features conserved in all cellulase CBDs from different bacteria. Although CBD has a critical role in hydrolyzing insoluble cellulose, some cellulases entirely lack this domain (Gilkes et

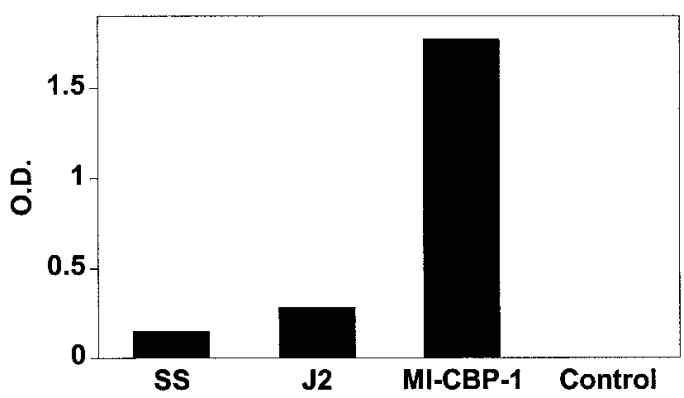

Fig. 5. Enzyme-linked immunosorbent assay of concentrated stylet secretions (SS) and total extracts (J2) of Meloidogyne incognita secondstage juveniles and recombinant MI-CBP-1 with polyclonal antiserum raised against recombinant $\mathrm{MI}-\mathrm{CBP}-1$. Control coated only with bovine serum albumin.

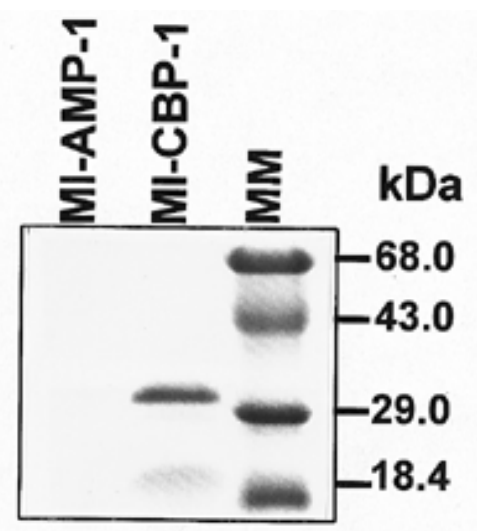

Fig. 6. Sodium dodecyl sulfate-polyacrylamide gel electrophoresis of recombinant MI-CBP-1 eluted from a CBIND column. Recombinant MI-AMP-1 was used as a negative control. $\mathrm{MM}=$ molecular mass markers. 
al. 1991). In fact, one of the two $\beta-1,4-e n d o g l u c a n a s e ~ c D N A s$ cloned from each of two species of cyst nematodes lacked a CBD (Smant et al. 1998). Furthermore, although some catalytic domains still possess cellulase activity when they are separated from the CBD by proteolytic cleavage, the ability to hydrolyze insoluble cellulose is dramatically reduced in comparison with the intact enzyme (Gilkes et al. 1988).

Alternatively, MI-CBP-1 might have other functions mediated by an interaction of the N-terminal sequence (unknown function) and the CBD. Possibly, MI-CBP-1 might directly or indirectly have a role in early giant-cell induction by its $\mathrm{CBD}$ serving as an anchor domain to assist the $\mathrm{N}$-terminal domain to function. An interaction of the $\mathrm{N}$-terminal sequence and the

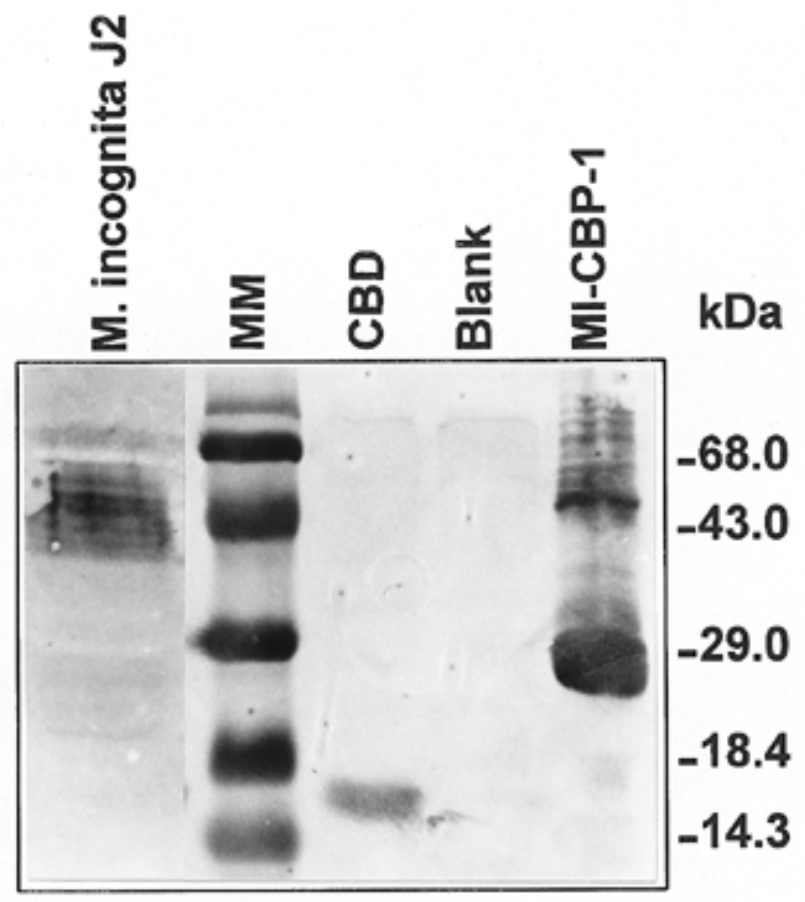

Fig. 7. Immunoblot analysis of extracts of Meloidogyne incognita second-stage juveniles (J2), recombinant MI-CBP-1, and recombinant cellulose-binding domain (CBD) derived from $M i$-c $b p-1$ with polyclonal antiserum raised against recombinant MI-CBP-1. $\mathrm{MM}=$ molecular mass markers.

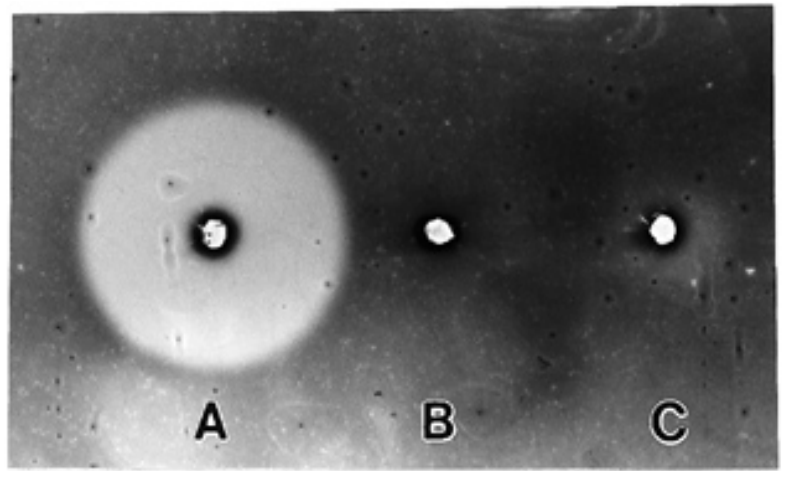

Fig. 8. Agarose plate assay for cellulase activity with carboxymethylcellulose (CMC) as substrate. A, Cellulase from Aspergillus niger. B, Extraction buffer alone. C, Recombinant MI-CBP-1 from Meloidogyne incognita. Gel containing CMC was stained with Congo red to detect activity indicated by the clear zone.
CBD is made possible by the Q-linker, which also occurs in cellulases, xylanases, and bacterial regulatory and sensory proteins (Gilkes et al. 1991). Furthermore, to assure connection between these two domains, N-glycosylation of the linker could protect MI-CBP-1 from proteolytic cleavage, as reported for bacterial cellulase (Langsford et al. 1987). Interestingly, some polysaccharide-binding proteins, e.g., the pilusassociated adhesion protein and the carbohydrate recognition domain of animal lectin, have the same conserved glycine residues as MI-CBP-1 (Gilkes et al. 1991). In addition, CBDs have been isolated from proteins that have no apparent hydrolytic activity (Goldstein et al. 1993; Morag et al. 1995) and a recombinant $\mathrm{CBD}$ enhanced elongation of different plant cells in vitro (Shpigel et al., in press). Giant-cell formation involves extensive cell elongation, although this is thought to occur from the general elongation of cells behind the root tip (Jones and Payne 1978). Further studies are needed to determine the actual function of the root-knot nematode secretory MI-CBP-1 in pathogenesis.

\section{MATERIALS AND METHODS}

Nematode cultures and collection of stylet secretions.

Meloidogyne incognita was cultured and collected from greenhouse-grown tomato plants (Lycopersicon esculentum cv. Rutgers) as described previously (Hussey and Barker 1973). Heterodera glycines was grown on greenhouse-grown soybean (Glycine max). Pre-parasitic $\mathrm{J} 2$ of both genera were collected by hatching eggs on sieves with $25-\mu \mathrm{m}$ openings suspended over deionized water in plastic bowls. Parasitic J2 and adult females of $M$. incognita were dissected from infected tomato roots. Mixed stages of $C$. elegans were maintained as monoxenic cultures on Escherichia coli (OP50) and collected by the method of Brenner (1974).

Stylet secretions from $M$. incognita $\mathrm{J} 2$ were produced and collected in vitro as described by Davis et al. (1994). Preparasitic J2 were incubated in $0.4 \%$ resorcinol (Sigma, St. Louis, MO) for $4 \mathrm{~h}$ at room temperature in a humid chamber. Stylet secretions were solubilized by adding an equal volume of $20 \mathrm{mM}$ Tris buffer at $\mathrm{pH} 12$ or $\mathrm{pH} 8.5$. Solubilized stylet secretions were concentrated with 10,000 MW cutoff Centricons (Amicon, Beverly, MA), resuspended in $300 \mu \mathrm{l}$ of Tris buffer, transferred to $0.5-\mu l$ microcentrifuge tubes, and stored at $-80^{\circ} \mathrm{C}$ until needed.

\section{Collection of infected root tissue.}

Soybean seeds were placed on water-saturated germination paper and germinated in the dark for 3 days at room temperature. The seedlings were placed on moist sand and the root tips were inoculated with $M$. incognita $\mathrm{J} 2$ and covered with sand. The inoculated soybeans were incubated in the dark at room temperature for $24 \mathrm{~h}$ to allow the $\mathrm{J} 2$ to invade the roots. The seedlings were then washed with sterile water, placed on wet germination paper, and incubated in the dark for another $24 \mathrm{~h}$ at room temperature. Infected root tips were excised and stored in centrifuge tubes at $-80^{\circ} \mathrm{C}$ for further use.

\section{Nucleic acid isolation.}

Genomic DNA was isolated from 1-month-old soybean leaves by a procedure described by Rogers and Bendich (1985). Genomic DNA was isolated from M. incognita J2, 
H. glycines $\mathrm{J} 2$, and $C$. elegans mixed stages as described by Ray et al. (1994). Total RNA was isolated from soybean roots and $M$. incognita $\mathrm{J} 2$ with TRIzol reagent (Life Technologies, Grand Island, NY). Poly(A) ${ }^{+}$RNA (mRNA) was isolated from $M$. incognita pre-parasitic and parasitic $\mathrm{J} 2$ and adult females with Dynabeads Oligo $(\mathrm{dT})^{25}$ magnetic beads (Dynal, Lake Success, NY) according to the manufacturer's instruction.

\section{RNA fingerprinting and nucleotide sequencing.}

RNA fingerprinting (McClelland et al. 1993) was performed with the Delta RNA Fingerprinting Kit (Clontech Laboratories, Palo Alto, CA) following the manufacturer's instruction with minor modifications. Briefly, $2 \mu \mathrm{g}$ of total RNA isolated from pre-parasitic $M$. incognita J2 (PPJ2), parasitic $M$. incognita $\mathrm{J} 2$ (PJ2), and $M$. incognita J2-infected soybean root tip tissues $(\mathrm{R})$ was reverse-transcribed into cDNAs. Polymerase chain reaction (PCR) fingerprinting reactions were accomplished with the synthesized cDNAs as templates, kit-provided T/P primers as $3^{\prime}$ and $5^{\prime}$ primers, and $\left[\alpha^{32} \mathrm{P}\right] \mathrm{dATP}$ as an isotope. Each PCR was performed twice to eliminate false positives. At the same time, negative controls were performed with the same PCR conditions as the above reactions, with water and total RNAs from PPJ2, PJ2, and R as templates. All the PCR products were fractionated on $5 \%$ polyacrylamide/8 M urea gels. DNA fragments that were specific or more strongly expressed for PJ2 were excised from the gel, re-amplified by PCR with the same primers, and cloned into pGEM-T vector (Promega, Madison, WI) for further sequencing, and Southern blot analyses.

DNA sequencing was done by the University of Georgia Molecular Genetics Instrumentation Facility by the fluorescent dye terminator method with Taq DNA polymerase.

\section{cDNA library construction and screening.}

Poly(A) ${ }^{+}$RNAs $(5 \mu \mathrm{g})$ isolated from $M$. incognita J2 were used for cDNA library construction (Sambrook et al. 1989). First-strand DNA was synthesized with oligo-dT as a primer. Following second-strand synthesis, the cDNAs were inserted into BstXI/NotI sites of pcDNA II (Invitrogen, Carlsbad, CA). The cDNA library contained $4.2 \times 10^{6}$ primary recombinants. cDNA library screening (Sambrook et al. 1989) was performed with the ${ }^{32} \mathrm{P}$-labeled (Feinberg and Vogelstein 1987), fingerprinting-derived F43 fragment as a probe.

\section{Southern blot hybridization.}

Southern blot hybridizations were done as previously described by Ray et al. (1994) with minor modifications. Genomic DNA $(10 \mu \mathrm{g})$ from $M$. incognita, M. hapla, M. arenaria, $M$. javanica, $H$. glycines, $C$. elegans, and soybean (Glycines max) was digested with EcoRI, fractionated in a $1 \%$ agarose gel, and transferred onto a Nytran filter (Schleicher \& Schuell, Keene, NH). High-stringency hybridization was performed at $62^{\circ} \mathrm{C}$ in hybridization buffer (7\% SDS, $1 \%$ bovine serum albumin [BSA], $1 \mathrm{mM} \mathrm{Na} \mathrm{NaDTA}_{2}$ 0.5 M $\left.\mathrm{Na}_{2} \mathrm{HPO}_{4}\right)$ overnight, and washed with $0.1 \times \mathrm{SSC}(1 \times \mathrm{SSC}$ is $0.15 \mathrm{M} \mathrm{NaCl}$ plus $0.015 \mathrm{M}$ sodium citrate), $0.1 \%$ SDS at $62^{\circ} \mathrm{C}$. Low stringency hybridization involved hybridization overnight at $55^{\circ} \mathrm{C}$ in the hybridization buffer and washing with $0.5 \times \mathrm{SSC}, 0.1 \% \mathrm{SDS}$ at $50^{\circ} \mathrm{C} .{ }^{32} \mathrm{P}$-labeled $\mathrm{Mi}$-cbp- 1 was used as the probe.

\section{Expression and purification of recombinant MI-CBP-1, MI-AMP-1, and CBD.}

A 549-bp fragment derived from the ORF of the Mi-cbp-1 was amplified by PCR (Sambrook et al. 1989) with the synthesized primers (5'-CGGGATCCGATGATGCTGGTAGAT ATC-3', 5'-GCGTCGACATATCCATATTTTTTATTCAAT-3') and $M i-c b p-1$ sequence as a template. A 683-bp fragment derived from the ORF of Mi-amp-1 (GenBank accession no. AF013289) from $M$. incognita was amplified by PCR with the synthesized primers 5'-CGGGATCCTCTTTGACTGTTCC TGAACAA- $3^{\prime}$ and 5'-GCGTCGACCAGCCCTCAAATAAA TTT- $3^{\prime}$ and $M i$-amp- 1 sequence as a template. Highest expression in E. coli was obtained when the leader sequence was deleted from each ORF (data not shown). The 228-bp fragment containing the CBD sequence from the $M i$-cbp-l clone was amplified by PCR with the synthesized primers (5'CGGGATCCATATTGAGAGATAAATGGGTAAATGGC-3', 5'-GCGTCGACATATCCATATTTTTTATTCAAT-3') and $\mathrm{Mi-}$ $c b p-1$ sequence of the $M i-c b p-1$ clone as a template. The amplified fragments were inserted into BamHI/SalI sites of expression vector pET 28A (Novagen, Madison, WI). The recombinant MI-CBP-1 or MI-AMP-1 were purified with NiNTA resin (Qiagen, Santa Clarita, CA) following the manufacturer's instruction.

\section{Antiserum production.}

Polyclonal antibodies to MI-CBP-1 were produced by injecting a New Zealand rabbit intradermally twice with purified recombinant MI-CBP-1. Purity was confirmed by SDSPAGE. Complete Freund's adjuvant was used for the initial injection and incomplete Freund's adjuvant for the 4-week boost injection.

\section{Protein extraction and immunoblotting.}

Proteins were extracted by grinding $M$. incognita preparasitic $\mathrm{J} 2$ in $200 \mu \mathrm{l}$ of extraction buffer (100 mM Tris, $\mathrm{pH}$ $7.0,150 \mathrm{mM} \mathrm{NaCl}$ ) in microcentrifuge tubes in liquid nitrogen. The homogenates were centrifuged at $20,000 \times g$ for 10 min. Protein concentration was estimated with a protein quantitation kit (Sigma Chemical, St. Louis, MO) with BSA as a standard. Proteins $(200 \mu \mathrm{g})$ were separated in SDS-PAGE and transferred to nitrocellulose-1 membranes (Life Technologies, Grand Island, NY) (Winston et al. 1987). The membrane was incubated in a blocking solution $(1 \%$ nonfat milk, $1 \times$ Tris-

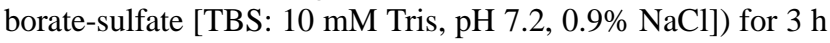
at $37^{\circ} \mathrm{C}$ and then treated with the MI-CBP-1 polyclonal antibodies, followed by anti-rabbit IgG (whole molecule) alkaline phosphatase conjugate (Sigma). The membrane was washed three times in $1 \times$ TBS buffer at room temperature and incubated in the substrate solution ( $44 \mu \mathrm{l}$ of nitroblue tetrazolium [NBT] solution and $33 \mu \mathrm{l}$ of 5-bromo-4-chloro-3-indolylphosphate toluidinium [BCIP] solution [5 Prime $\rightarrow 3$ Prime, Boulder, CO] in $10 \mathrm{ml}$ of AP buffer [100 mM Tris, $\mathrm{pH} 9.5$, $100 \mathrm{mM} \mathrm{NaCl}, 5 \mathrm{mM} \mathrm{MgCl}])$.

\section{MI-CBP-1 N-terminal-specific antibody production.}

Nitrocellulose membranes were first soaked in purified recombinant CBD dissolved in 1× TBS buffer for $2 \mathrm{~h}$ at room temperature, washed three times in $1 \times$ TBS buffer at room temperature, incubated in a blocking solution (1\% nonfat milk, $1 \times \mathrm{TBS}$ ) for $3 \mathrm{~h}$ at $37^{\circ} \mathrm{C}$, and then treated with the MI- 
CBP-1 polyclonal antibodies. This process was repeated until the CBD-specific antibodies were completely removed from the MI-CBP-1 polyclonal antiserum as determined by immunoblot analysis.

\section{$\beta-1,4-$ glucanase assay.}

A $\beta$-1,4-glucanase assay was performed as previously described by Mateos et al. (1992). Purified, recombinant MI-CBP-1 (1 $\mu \mathrm{g})$, cellulase from Penicillium funiculosum (Sigma \#C-0901, 0.08 units) as a positive control, and protein extraction buffer as a negative control were loaded into small holes in CMC agarose plates $(0.5 \%$ agarose, $0.2 \%$ carboxymethyl cellulose [Sigma], in phosphate citric acid buffer [0.05 $\mathrm{M} \mathrm{K}_{2} \mathrm{HPO}_{4}$, brought to $\mathrm{pH} 5.2$ with $1 \mathrm{M}$ citric acid]) and incubated at $30^{\circ} \mathrm{C}$ overnight. The agarose was stained with $0.1 \%$ Congo red in deionized water (Fisher Scientific, Pittsburgh, PA) at $30^{\circ} \mathrm{C}$ for $30 \mathrm{~min}$ and washed with $1 \mathrm{M} \mathrm{NaCl}$ solution.

\section{Immunofluorescence assay.}

The polyclonal antiserum (absorbed and nonabsorbed) was used to localize MI-CBP-1 in sections of pre-parasitic J2, parasitic $\mathrm{J} 2$, and adult females $M$. incognita, pre-parasitic $\mathrm{J} 2$ of $M$. arenaria, $M$. javanica, $M$. hapla, and $H$. glycines, and mixed stages of $C$. elegans with indirect immunofluorescence as described previously by Davis et al. (1994). Following fixation in freshly prepared $4 \%$ paraformaldehyde in $\mathrm{M} 9$ buffer $\left(22 \mathrm{mM} \mathrm{KH} \mathrm{KHO}_{4}, 42.3 \mathrm{mM} \mathrm{Na} \mathrm{HPO}_{4}, 85.6 \mathrm{mM} \mathrm{NaCl}\right.$, $1 \mathrm{mM} \mathrm{MgSO}_{4}, \mathrm{pH} \mathrm{7.4)}$ for $4 \mathrm{~h}$ at room temperature, the nematodes were washed three times in M9 buffer and once in deionized water. The fixed nematodes were cut into sections and incubated in $2 \mathrm{mg}$ of proteinase $\mathrm{K}$ (Sigma) per $\mathrm{ml}$ in enzyme buffer (100 mM Tris- $\mathrm{HCl}, 1 \mathrm{mM} \mathrm{CaCl}{ }_{2}, 0.1 \%$ Triton $\mathrm{X}$ $100, \mathrm{pH} \mathrm{7.4)}$ at room temperature for $20 \mathrm{~min}(\mathrm{~J} 2$ and C. elegans) or $40 \mathrm{~min}$ (adult females). The enzyme solution was removed and sections were placed in a $-80^{\circ} \mathrm{C}$ freezer for 20 min, incubated in ice-cold methanol for $30 \mathrm{~s}$, then incubated in ice-cold acetone for $90 \mathrm{~s}$. The sections were quickly brought to near dryness with a stream of air and rehydrated by slowly adding $500 \mu \mathrm{l}$ of deionized water. The water was removed and sections were resuspended in blocking solution (10\% goat serum, $0.02 \% \mathrm{NaN}_{3}, 1 \mathrm{mM}$ phenylmethylsulfonyl fluoride, phosphate buffered saline [PBS]), incubated for $3 \mathrm{~h}$ and then used immediately for immunofluorescence or stored at $-80^{\circ} \mathrm{C}$ until needed.

\section{Plant cell binding assay.}

Purified recombinant MI-CBP-1 solution (100 $\mu \mathrm{g}$ of MICBP-1, 30\% glycerol, 1× TBS), recombinant MI-AMP-1(100 $\mu \mathrm{g}$ of Mi-AMP-1, 30\% glycerol, $1 \times$ TBS), secondary antibody alone or buffer only as a negative control (30\% glycerol, $1 \times$ TBS) were added to $200-\mathrm{ml}$ culture flasks containing $50 \mathrm{ml}$ of fresh tobacco (Nicotiana tabacum var. BY2) cell suspension culture $(4.3 \mathrm{~g}$ of Murashige \& Skoog salt mixture, $30 \mathrm{~g}$ of sucrose, $0.1 \mathrm{mg}$ of myoinositol, $0.1 \mathrm{mg}$ of thiamin $\mathrm{HCl}$, and 0.1 $\mathrm{mg}$ of 2,4-D (2,4-dichlorophenoxyacetic acid) per liter, 1,000 cells per ml) (Nagata et al. 1992). The culture was kept in the dark and incubated at $28^{\circ} \mathrm{C}$ for 3 days in a shaker running at 200 rpm (Gyrotory Shaker, model G2; New Brunswick Scientific, Edison, NJ). The cells were fixed and labeled according to the procedure described above for the immunofluorescence assay, but the post-fixation steps of proteinase $\mathrm{K}$, acetone, and methanol treatments were omitted.

\section{Cellulose-binding assay.}

Binding of the recombinant MI-CBP-1 to cellulose was performed with CBIND 100 resin (Novagen, Madison, WI) according to manufacturer's instruction. Twenty microliters of purified recombinant MI-CBP-1 solution (20 $\mu \mathrm{g}$ of MI-CBP-1, $20 \mathrm{mM}$ Tris-HCl, $\mathrm{pH}$ 7.5) was mixed with $2 \mathrm{mg}$ of CBIND resin. The protein was eluted with water and then separated on SDS-PAGE. Under the same conditions, purified recombinant MI-AMP1 was used as a negative control.

\section{ELISA.}

ELISA was performed according to Pratt et al. (1986). Briefly, Immulon (Dynatech, Fisher) plate wells were coated overnight at $4{ }^{\circ} \mathrm{C}$ with $10 \mu \mathrm{g}$ of total protein diluted in borate saline (0.2 $\mathrm{M}$ sodium borate, $75 \mathrm{mM} \mathrm{NaCl}, \mathrm{pH} 8.5)$ from the following sources: extracts of $M$. incognita pre-parasitic J2 and solubilized stylet secretions of $M$. incognita J2 or BSA (Sigma) as a negative control. As a positive control, wells were coated with $10 \mu \mathrm{g}$ of recombinant MI-CBP-1. Wells were rinsed three times with wash buffer $(10 \mathrm{mM}$ Tris, $0.5 \mathrm{M}$ $\mathrm{NaCl}, \mathrm{pH}$ 8.0) and blocked with $1 \%$ BSA in PBS (32.9 mM $\mathrm{Na}_{2} \mathrm{HPO}_{4}, 1.77 \mathrm{mM} \mathrm{NaH} \mathrm{PO}_{4}, 0.14 \mathrm{M} \mathrm{NaCl}, \mathrm{pH}$ 7.4) for 30 $\mathrm{min}$ at room temperature. After being rinsed once with wash buffer, each coated well was incubated with MI-CBP-1 polyclonal antisera diluted 1:1,000 with $0.5 \%$ BSA in PBS for $1 \mathrm{~h}$ at room temperature. Negative controls included omitting incubation with the primary polyclonal antibody. The wells were washed three times, incubated with alkaline phosphatase-conjugated goat anti-rabbit antibody (Sigma) at 1:5,000 dilution for $1 \mathrm{~h}$ at room temperature, and washed three times before phosphate colorimetric substrate was added. The substrate, p-nitrophenyl phosphate (Sigma 104), was prepared according to manufacturer's directions in alkaline phosphatase buffer ( $1 \mathrm{M}$ diethanolamine, $0.5 \mathrm{mM} \mathrm{MgCl} 2, \mathrm{pH} 9.8$ ) and incubated in treated wells $30 \mathrm{~min}$ at room temperature before the reaction was stopped with $3 \mathrm{~N} \mathrm{NaOH}$. Absorbance was measured at $405 \mathrm{~nm}$ on an ELISA reader (Titertek Multiskan MCC/340, EF Labs, Finland).

\section{ACKNOWLEDGMENTS}

Support for this research was provided by the National Research Initiative Competitive Grants Program of the U.S. Department of Agriculture under Agreement Nos. 93-37302-8967 and 96-35302-3771, and by state and Hatch funds allocated to the Georgia Agricultural Experiment Stations.

\section{LITERATURE CITED}

Altschul, S. F., Warren, G., Webb, M., Eugene, W. M., and David, J. L.. 1990. Basic local alignment search tool. J. Mol. Biol. 215:403-10.

Bairoch A., Bucher P., and Hofmann K. 1995. The PROSITE database, its status in 1995. Nucleic Acid Res. 24:189-196.

Brenner, S. 1974. The genetics of the nematode Caenorhabditis elegans. Genetics 77:71-94.

Davis, E. L., Allen, R., and Hussey, R. S. 1994. Developmental expression of esophageal gland antigens and their detection in stylet secretions of Meloidogyne incognita. Fundam. Appl. Nematol. 17:255-262.

Feinberg, A. P., and Vogelstein, B. 1987. A technique for radiolabeling DNA restriction endonuclease fragments to high specific activities. Anal. Biochem. 132:6-13. 
Gilkes, N. R., Henrissat, B., Kilburn, D. G., Miller, R. C., Jr., and Warren, R. A. J. 1991. Domains in microbial $\beta$-1,4-glycanases: Sequence conservation, function, and enzyme families. Microbiol. Rev. 55:301-315.

Gilkes, N. R., Warren, R. A. J., Miller, R. C., Jr., and Kilburn, D. G. 1988. Precise excision of the cellulose binding domain from two Cellulomonas fimi cellulases by a homologous protease and the effect on catalysis. J. Biol. Chem. 263:10401-10407.

Goldstein, M. A., Takagi, M., Hashida, S., Shoseyov, O., Doi, R. H., and Segel, I. H. 1993. Characterization of the cellulose-binding domain of the Clostridium cellulovorans cellulose-binding protein A. J. Bacteriol. 175:5762-5768.

Hussey, R. S. 1985. Host-parasite relationships and associated physiological changes. Pages 144-153 in: An Advanced Treatise on Meloidogyne. Vol. 1. Biology and Control. N. N. Sasser and C. C. Carter, eds. N. C. State Univ. Graphics, Raleigh.

Hussey, R. S., and Barker, K. R. 1973. A comparison of methods of collecting inocula of Meloidogyne spp., including a new technique. Plant Dis. Rep. 57:1025-1028.

Hussey, R. S., Davis, E. L., and Ray, C. 1994. Meloidogyne stylet secretions. Pages 233-249 in: Advances in Molecular Nematology. F. Lamberti, C. DiGiorgio, and D. Mck. Bird, eds. Plenum Press, New York.

Hussey, R. S. and Mims, C. W. 1990. Ultrastructure of esophageal glands and their secretory granules in the root-knot nematode Meloidogyne incognita. Protoplasma 156:9-18.

Jones, M. G. K., and Payne, H. L. 1978. Early stage of nematodeinduced giant-cell formation in roots of Impatiens balsamina. J. Nematol.10:70-84

Langsford, M. L., Gilkes, N. R., Singh, B., Moser, B., Miller, R. C., Jr., Warren, R. A. J., and Kilburn, D. G. 1987. Glycosylation of bacterial cellulases prevents proteolytic cleavage between functional domains. FEBS Lett. 225:163-167.

Mateos, P. F., Jimenez-Zurdo, J. I., Chen, J., Squartini, A. S., Haack, S. K., Martinez-Molina, E., Hubbell, D. H., and Dazzo, F. B. 1992. Cellassociated pectinolytic and cellulolytic enzymes in Rhizobium leguminosarum biovar trifolii. Appl. Environ. Microbiol. 58:1816-1822.

McClelland, M., Chada, K., Welsh, J., and Ralph, D. 1993. Arbitrary primed PCR fingerprinting of RNA applied to mapping differentially expressed genes. Pages 103-115 in: DNA Fingerprinting: State of the Science. S. D. J. Pena, R. Chakraborty, J. T. Epplen, and A. J. Jeffreys, eds. Mirkhauser Verlag, Boston.

Morag, E., Lapidot, A., Govorko, D., Lamed, R., Wilcheck, M., Bayer, E. A., and Shoham, Y. 1995. Expression, purification, and characterization of the cellulose-binding domain of the scaffoldin subunit from the cellulosome of Clostridium thermocellum. Appl. Environ. Microbiol. 61:1980-1986.

Nagata, T., Nemoto, Y., and Hasezawa, S. 1992. Tobacco BY-2 cell line as the Hela cell in the cell biology of higher plants. Int. Rev. Cytol. 132:1-30.

Nielsen, H., Engelbrecht, J., Brunak, S., and von Heijne, G. 1997. Identification of prokaryotic and eukaryotic signal peptides and prediction of their cleavage sites. Protein Eng. 10:1-6.

Pratt, L. H., McCurdy, D. W., Shimazaki, Y., and Cordonnier, M.-M. 1986. Immunodetection of phytochrome: immunocytochemistry, immunoblotting, and immunoquantitation. Pages 50-74 in: Modern Methods of Plant Analysis, New Series, Vol. 4. H. F. Linskens and J. F. Jackson, eds. Springer-Verlag, New York.

Ray, C., Abbott, A. G., and Hussey, R. S. 1994. Trans-splicing of a Meloidogyne incognita mRNA encoding a putative esophageal gland protein. Mol. Biochem. Parasitol. 68:93-101.

.Rogers, S. O., and Bendich, A. J. 1985. Extraction of DNA from milligram amounts of fresh, herbarium and mummified plant tissues. Plant Mol. Biol. 5:69-76.

Sambrook, J., Fritsch. E. R., and Maniatis, T. A. 1989. Molecular Cloning. A Laboratory Manual. 2nd ed. Cold Spring Harbor Laboratory, Cold Spring Harbor, NY.

Sasser, J. N., and Freckman, D. W. 1987. A world perspective on nematology: The role of the society. Pages 7-14 in: Vistas on Nematology: A Commemoration of the Twenty-fifth Anniversary of the Society of Nematologists. J. A. Veech and D. W. Dickson, eds. Society of Nematologists, Hyattsville, MD.

Shpigel, E., Roiz, L., Goren, R., and Shoseyov, O. Bacterial cellulasebinding domain modulates in vitro elongation of different plant cells. Plant Physiol. (In press.)

Smant, G., Stokkermans, J. P. W. G., Yitang, Y. , deBoer, J. M., Baum, T., Wang, X., Hussey, R. S., Gommers, F. J., Henrissat, B., Davis, E. L., Helder, J., Shots, A., and. Bakker, J. 1998. Endogenous cellulases in animals: Isolation of $\beta$-1,4-endoglucanase genes from two species of plant-parasitic cyst nematodes. Proc. Natl. Acad. Sci. USA 95: 4906-49011.

Smith, R. F., and Smith, T. F. 1992. Pattern-Induced Multi-sequence Alignment (PIMA) algorithm employing secondary structuredependent gap penalties for comparative protein modeling. Protein Eng. 5:35-41.

Williamson, V. M., and Hussey, R. S. 1996. Nematode pathogenesis and resistance in plants. Plant Cell 8:1735-1745.

Winston, S. E., Fuller, S. A., and Hurrell, J. G. R. 1987. Western blotting. Pages 10.8.1-10.8.6 in: Current Protocols in Molecular Biology. F. M. Ausubel, R. Brent, R. E. Kingston, D. D. Moore, J. G. Seidman, J. A. Smith, and K. Struhl, eds. John Wiley and Sons, New York.

Wyss, U., Grundler, F. M. W., and Münch, A. 1992. The parasitic behaviour of second-stage juveniles of Meloidogyne incognita in roots of Arabidopsis thaliana. Nematologica 38:98-111. 